\title{
MODEL PENGARUH IKLIM KESELAMATAN TERHADAP PERILAKU KESELAMATAN DENGAN DETERMINAN PENGETAHUAN DAN MOTIVASI PADA PROYEK KONSTRUKSI
}

\author{
Priscillia Syaranamual ${ }^{1}$, Herry P. Chandra² ${ }^{\text {, Paulus Nugraha }}{ }^{3}$
}

\begin{abstract}
ABSTRAK: Pada proyek konstruksi, angka kecelakaan kerja yang terjadi masih tinggi. Salah satu penyebabnya adalah kurang patutnya para tenaga kerja terhadap aturan. Oleh karena itu, perlu mengetahui faktor iklim keselamatan apa saja yang berpengaruh terhadap perilaku keselamatan dengan determinan pengetahuan dan motivasi. Model yang digunakan diadopsi dari model Neal \& Griffin (2000), setelah itu dimodifikasi dengan menambahkan indikator untuk setiap variabel. Penelitian menggunakan sampel sebanyak 147 orang. Penelitian dilakukan pada proyek konstruksi di Surabaya. Selanjutnya semua kuesioner dianalisis menggunakan Structural Equation Model. Dalam penelitian ini mempunyai 6 hipotesa. Dari hasil pengujian, dapat di ketahui bahwa iklim keselamatan mempunyai pengaruh positif terhadap perilaku keselamatan. Iklim keselamatan mempunyai pengaruh terhadap pengetahuan dan motivasi dengan nilai direct-effect sebesar 0,844 dan 0,725. Sedangkan pengetahuan mempunyai pengaruh terhadap kepatuhan dan partsipasi keselamatan dengan nilai direct-effect sebesar 0,147 dan 0,244 dan motivasi mempunyai pengaruh terhadap kepatuhan dan partsipasi keselamatan dengan nilai direct-effect sebesar 0,787 dan 0,737.
\end{abstract}

Kata kunci: faktor iklim keselamatan, faktor perilaku keselamatan, pengetahuan, motivasi dan proyek konstruksi.

\section{PENDAHULUAN}

Dalam dunia konstruksi kecelakaan kerja masih sering terjadi, hal ini ditunjukkan dengan masih tingginya angka kecelakaan kerja yang terjadi pada proyek kontruksi. Salah satu penyebab utama timbulnya kecelakaan kerja karena kurang patuhnya para tenaga kerja dalam pemakaian alat pelindung diri. menurut Neal dan Griffin (2002) salah satu hal yang mempengaruhi kepatuhan terhadap peraturan keselamatan tersebut adalah iklim keselamatan. Persepsi iklim keselamatan dapat mempengaruhi sikap pekerja terhadap keselamatan, cara pekerja melaksanakan pekerjaan dan cara pekerja berinteraksi sesama pekerja yang mempunyai dampak langsung pada hasil keselamatan seperti kecelakaan kerja pada perusahaan. Untuk itu perlu diketahui dan dianalisis faktor-faktor iklim keselamatan yang berpengaruh pada perilaku keselamatan, sehingga kecelakaan kerja dapat diminimalisir. Oleh karena itu, perlu diadakan analisis tentang model pengaruh iklim keselamatan terhadap perilaku keselamatan dengan determinan pengetahuan dan motivasi pada proyek konstruksi

\footnotetext{
${ }_{1}$ Mahasiswa Program Studi Magister Teknik Sipil Universitas Kristen Petra, m01514024@john.petra.ac.id

2 Dosen Program Studi Magister Teknik Sipil Universitas Kristen Petra, herrypin@peter.petra.ac.id

${ }^{3}$ Dosen Program Studi Magister Teknik Sipil Universitas Kristen Petra, pnugraha.@peter.petra.ac.id
} 
Tujuan penelitian ini yaitu mengidentifikasi iklim keselamatan yang berpengaruh pada perilaku keselamatan dan membuat model model pengaruh iklim keselamatan terhadap perilaku keselamatan dengan determinan pengetahuan dan motivasi pada proyek konstruksi. Hasil penelitian ni diharapkan dapat memberikan masukan bagi kalangan akademik lainnya sebagai tambahan informasi untuk penelitian-penelitian selanjutnya dan pihak-pihak yang terlibat dalam dunia konstruksi untuk lebih memperhatikan iklim keselamatan terhadap perilaku keselamatan dengan determinan pengetahuan dan motivsi pada proyek konstruksi.

\section{TINJAUAN PUSTAKA}

\subsection{Faktor-Faktor Iklim Keselamatan}

Menurut Griffin \& Neal (2002) Iklim keselamatan menggambarkan persepsi pekerja tehadap nilai keselamatan dalam sebuah organisasi. Dan Flin, et al. (2000) meninjau bahwa Iklim keselamatan sebagai usaha menentukan pengaruh organisasi, manajemen, dan faktor manusia sebagai ukuran Iklim keselamatan. Tabel 1. menunjukkan faktor-faktor iklim keselamatan.

Tabel 1. Faktor-Faktor Iklim Keselamatan

\begin{tabular}{|c|c|c|c|c|c|c|c|c|c|}
\hline \multirow{2}{*}{ No } & \multirow{2}{*}{ Faktor-Faktor } & \multicolumn{8}{|c|}{ Sumber Faktor } \\
\hline & & 1 & 2 & 3 & 4 & 5 & 6 & 7 & 8 \\
\hline 1 & Inspeksi keselamatan & $\mathrm{x}$ & & & $\mathrm{x}$ & & & & $\mathrm{x}$ \\
\hline 2 & Pelatihan & $\mathrm{x}$ & & & & $x$ & & & $x$ \\
\hline 3 & Kecukupan prosedur & & & $x$ & & & $\mathrm{x}$ & & \\
\hline 4 & Tekanan kerja & & & & & & $\mathrm{x}$ & $x$ & \\
\hline 5 & Alat pelindung diri & & & $x$ & & & $\mathrm{x}$ & & \\
\hline 6 & Hubungan dalam organisasi & & & & & & $\mathrm{x}$ & & \\
\hline 7 & Sistem dan Peraturan Keselamatan & & $\mathrm{x}$ & & & & $x$ & $x$ & \\
\hline 8 & Risiko & & $\mathrm{x}$ & $x$ & & $\mathrm{x}$ & & & \\
\hline 9 & Kompetensi & & & & $x$ & & & $\mathrm{x}$ & \\
\hline 10 & Komitmen manajemen & $\mathrm{x}$ & $\mathrm{x}$ & $x$ & $\mathrm{x}$ & $\mathrm{x}$ & & $\mathrm{x}$ & $\mathrm{x}$ \\
\hline 11 & Komunikasi keselamatan & & & & & & $\mathrm{x}$ & & $x$ \\
\hline 12 & Dukungan teman kerja dan pengawasan & $\mathrm{x}$ & & $\mathrm{x}$ & $\mathrm{x}$ & & $\mathrm{x}$ & & \\
\hline
\end{tabular}

Keterangan :

1. Liu, et al. (2015)

2. Vinodkumar \& Bhasi (2009)

3. Teo \& Feng (2009)

5. Cooper \& Phillips (2004)

4. Seo, et al. (2004)

6. Glendon \& Litherland (2001)

7. Flin, et al. (2000)

8. Griffin \& Neal (2000)

\subsection{Faktor-Faktor Perilaku Keselamatan}

Borman dan Motowidlo (1993) membedakan perilaku keselamatan di tingkat individu ke dalam dua kategori, yaitu kepatuhan keselamatan (safety compliance) dan partisipasi keselamatan (safety participation). Kepatuhan keselamatan didefinisikan sebagai aktivitas utama yang harus dilakukan individu untuk mempertahankan keselamatan di tempat kerja, termasuk didalamnya kepatuhan akan prosedur kerja dan menggunakan peralatan pelindung diri (personal protective equipment). Di sisi lain partisipasi keselamatan didefinisikan sebagai perilaku yang tidak secara langsung berkontribusi terhadap aktivitas keselamatan, tetapi akan membantu lingkungan kerja untuk tetap selamat. Tabel 2. menunjukkan faktor perilaku keselamatan. 
Tabel 2. Faktor Perilaku Keselamatan

\begin{tabular}{|c|c|c|c|c|c|c|c|c|c|c|c|c|c|c|}
\hline \multirow{2}{*}{ No } & \multirow{2}{*}{$\begin{array}{l}\text { Faktor Perilaku } \\
\text { Keselamatan }\end{array}$} & \multicolumn{6}{|c|}{ Sumber } & \multirow{2}{*}{ Sub Faktor } & \multicolumn{6}{|c|}{ Sumber } \\
\hline & & 1 & 2 & 3 & 4 & 5 & 6 & & 1 & 2 & 3 & 4 & 5 & 6 \\
\hline \multirow{4}{*}{1} & \multirow{4}{*}{$\begin{array}{l}\text { Kepatuhan } \\
\text { keselamatan }\end{array}$} & \multirow{4}{*}{$\mathrm{x}$} & \multirow{4}{*}{$\mathrm{x}$} & \multirow{4}{*}{$\mathrm{x}$} & \multirow{4}{*}{$\mathrm{x}$} & \multirow{4}{*}{$\mathrm{x}$} & \multirow{4}{*}{$\mathrm{x}$} & Menaati prosedur kerja & & & $\mathrm{x}$ & $\mathrm{x}$ & $x$ & \\
\hline & & & & & & & & Menggunakan alat pelindung & & & $x$ & $x$ & $x$ & \\
\hline & & & & & & & & $\begin{array}{l}\text { Melaksanakan pekerjaan dengan } \\
\text { cara yang aman }\end{array}$ & & & & & & $x$ \\
\hline & & & & & & & & $\begin{array}{l}\text { Membersihkan lokasi/meja kerja } \\
\text { setelah pekerjaan berakhir }\end{array}$ & & & $\mathrm{x}$ & & & \\
\hline \multirow{4}{*}{2} & \multirow{4}{*}{$\begin{array}{l}\text { Partisipasi } \\
\text { keselamatan }\end{array}$} & \multirow{4}{*}{\multicolumn{2}{|c|}{$\mathrm{x}$}} & \multirow{4}{*}{\multicolumn{2}{|c|}{$x \mid>$}} & \multirow{4}{*}{$\mathrm{x}$} & \multirow{4}{*}{$\mathrm{x}$} & Membantu rekan kerja & & & & & $x$ & $x$ \\
\hline & & & & & & & & Menghadiri rapat keselamatan & & & & & $\mathrm{x}$ & $\mathrm{x}$ \\
\hline & & & & & & & & $\begin{array}{l}\text { Mengikuti kegiatan keselamatan } \\
\text { secara sukarela }\end{array}$ & & & & $\mathrm{x}$ & $\mathrm{x}$ & $x$ \\
\hline & & & & & & & & $\begin{array}{l}\text { Mempromosikan program } \\
\text { keselamatan kerja di tempat kerja }\end{array}$ & & & & & & $\mathrm{x}$ \\
\hline
\end{tabular}

Keterangan :
1. Guo, et al. (2016)
4. Cooper \& Philips (2004)
2. Smith, et al. (2016)
5. Neal \& Griffin (2000)
3. Liu, et al. (2015)
6. Neal, et al. (2000)

\subsection{Pengetahuan dan Motivasi}

Motivasi menurut Munandar (2001) diartikan sebagai suatu proses dimana kebutuhan-kebutuhan mendorong seseorang untuk melakukan serangkaian kegiatan yang mengarah pada tercapainya tujuan tertentu. Sedangkan jika pengetahuan seseorang semakain luas maka semakin positif perilaku yang dilakukannya. Tabel 3. menunjukkan faktor determinan pengetahuan dan motivasi.

Tabel 3. Faktor Determinan Pengetahuan dan Motivasi

\begin{tabular}{|c|c|c|c|c|}
\hline No & $\begin{array}{l}\text { Faktor } \\
\text { Determinan }\end{array}$ & Sumber & Sub Faktor & Sumber \\
\hline \multirow{4}{*}{1} & \multirow{4}{*}{ Pengetahuan } & \multirow{4}{*}{$\begin{array}{c}\text { Guo, et al. } \\
\text { (2016), } \\
\text { Neal \& Griffin } \\
(2000) \\
\text { Neal, et al. } \\
(2000)\end{array}$} & $\begin{array}{l}\text { Mampu menggunakan perlengkapan, } \\
\text { peralatan dan mesin dengan cara yang } \\
\text { aman }\end{array}$ & $\begin{array}{l}\text { Guo, et al. } \\
(2016)\end{array}$ \\
\hline & & & $\begin{array}{l}\text { Mampu mempertahankan atau meningkatkan } \\
\text { kesehatan dan keselamatan kerja }\end{array}$ & $\begin{array}{l}\text { Guo, et al. } \\
(2016)\end{array}$ \\
\hline & & & $\begin{array}{l}\text { Mampu mengurangi risiko kecelakanan dan } \\
\text { insiden di lapangan }\end{array}$ & $\begin{array}{l}\text { Guo, et al. } \\
(2016)\end{array}$ \\
\hline & & & $\begin{array}{l}\text { Mampu mengetahui bahaya yang } \\
\text { berhubungan dengan pekerjaan dan tindakan } \\
\text { pencegahan yang perlu diambil saat } \\
\text { melakukan pekerjaan }\end{array}$ & $\begin{array}{l}\text { Guo, et al. } \\
(2016)\end{array}$ \\
\hline \multirow{4}{*}{2} & \multirow{4}{*}{ Motivasi } & \multirow{4}{*}{$\begin{array}{c}\text { Guo, et al. } \\
\text { (2016), } \\
\text { Neal \& Griffin } \\
(2000) \\
\text { Neal, et al. } \\
(2000)\end{array}$} & $\begin{array}{l}\text { Jika pekerjaan aman, maka dapat bekerja } \\
\text { dengan nyaman dan enak }\end{array}$ & $\begin{array}{l}\text { Guo, et al. } \\
(2016)\end{array}$ \\
\hline & & & $\begin{array}{l}\text { Suka melakukan pekerjaan dengan cara yang } \\
\text { aman dan hati-hati }\end{array}$ & $\begin{array}{l}\text { Guo, et al. } \\
(2016)\end{array}$ \\
\hline & & & $\begin{array}{l}\text { Tidak merasa nyaman dan sejahtera, jika } \\
\text { lingkungan kerja tidak aman }\end{array}$ & $\begin{array}{l}\text { Guo, et al. } \\
(2016)\end{array}$ \\
\hline & & & $\begin{array}{l}\text { Merasa bersalah, jika tidak bekerja dengan } \\
\text { cara yang aman }\end{array}$ & $\begin{array}{l}\text { Guo, et al. } \\
(2016)\end{array}$ \\
\hline
\end{tabular}




\section{METODE PENELITIAN}

Dalam penelitian ini menggunakan jenis penelitian deskriptif kuantitatif. Dengan definisi konseptual dalam penelitian ini adalah model pengaruh iklim keselamatan terhadap perilaku keselamatan dengan determinan pengetahuan dan motivasi pada proyek konstruksi, sedangkan definisi operasional variabel adalah faktor iklim keselamatan (IK), pengetahuan $(\mathrm{P})$, motivasi $(\mathrm{M})$, kepatuhan keselamatan (KK) dan partisipasi keselamatan (PK).

Teknik pengambilan sampel yang digunakan adalah non probalility sampling, yaitu judgemental sampling. Jumlah responden sebanyak 1140-280 orang, dengan pertimbangan yang digunakan untuk memilih responden bidang konstruksi yaitu project manager, site manager dan safety officer dan site engineer. Penelitian ini dilakukan di Surabaya dan skala pengukuran data dalam penelitian ini dilakukan dengan menggunakan rentang skala likert.

Metode pengumpulan data yang digunakan yaitu pertama, dengan melakukan studi literatur dari jurnal, buku teks dan lain-lain. Kedua, Penelitian lapangan dengan melakukan penyusunan dan penyebaran kuisioner. Sedangkan analisis data menggunakan Structural Equation Model (SEM) dengan menggunakan AMOS.

\section{ANALISA DATA}

\subsection{Deskripsi Data}

Pada penelitian ini, digunakan proyek-proyek konstruksi yang ada di Kota Surabaya. Untuk mendapatkan data-data penelitian, maka penyebaran kuesioner dilakukan pada proyek konstruksi dari bulan Agustus hingga bulan September 2016. Selama survey dilakukan, kuesioner yang disebarkan berjumlah 180 kuesioner dan berhasil didapatkan sebanyak 147 kuesioner.

\subsection{Hasil Analisis Deskriptif}

Pada Tabel 4. Menunjukkan data responden yang digunakan untuk mengetahui identitas dari responden pada penelitian ini.

Tabel 4. Data Responden

\begin{tabular}{|c|c|c|c|c|c|}
\hline Pendidikan & Pengalaman & $\begin{array}{l}\text { Serifikat } \\
\text { SMK3 }\end{array}$ & Jabatan & Jenis Proyek & $\begin{array}{l}\text { Jumlah } \\
\text { Lantai }\end{array}$ \\
\hline $\mathrm{S} 1=119$ orang & $\begin{array}{l}<5 \text { Tahun }= \\
48 \text { orang }\end{array}$ & $\begin{array}{l}<5 \text { Tahun } \\
=17 \text { orang }\end{array}$ & $\begin{array}{l}\mathrm{PM}=20 \\
\text { orang }\end{array}$ & $\begin{array}{l}\text { Perkantoran }=29 \\
\text { orang }\end{array}$ & $\begin{array}{l}<5 \text { Tahun } \\
=15 \text { orang }\end{array}$ \\
\hline $\mathrm{S} 2=3$ orang & $\begin{array}{l}5-10 \text { Tahun }= \\
55 \text { orang }\end{array}$ & $\begin{array}{l}\text { 5-10 Tahun } \\
=37 \text { orang }\end{array}$ & $\begin{array}{l}\mathrm{SM}=36 \\
\text { orang }\end{array}$ & $\begin{array}{l}\text { Apartemen/Hotel }=77 \\
\text { orang }\end{array}$ & $\begin{array}{l}5-10 \text { Tahun } \\
=28 \text { orang }\end{array}$ \\
\hline \multirow[t]{3}{*}{$\begin{array}{l}\text { D1/D2/D3/SMA } \\
\text { SEDERAJAT = } \\
25 \text { orang }\end{array}$} & $\begin{array}{l}>10 \text { Tahun }= \\
44 \text { orang }\end{array}$ & $\begin{array}{l}>10 \text { Tahun } \\
=93 \text { orang }\end{array}$ & $\begin{array}{l}\mathrm{SO}=42 \\
\text { orang }\end{array}$ & $\begin{array}{l}\text { Perkantoran/Hotel/Mall } \\
\text { /Apartemen = } 16 \text { orang }\end{array}$ & $\begin{array}{l}>10 \text { Tahun } \\
=104 \text { orang }\end{array}$ \\
\hline & & & $\begin{array}{l}\text { SE }=29 \\
\text { orang }\end{array}$ & lainnya $=25$ orang & \\
\hline & & & $\begin{array}{l}\text { lainnya }= \\
29 \text { orang }\end{array}$ & & \\
\hline
\end{tabular}

\subsection{Hasil Analisis Faktor Konfirmatori}

Analisa faktor juga merupakan metode analisis yang bertujuan untuk mendapatkan sejumlah faktor yang memiliki sifat-sifat yang mampu menerangkan keragaman data (Hidayat \& Istiadah, 2011). Pada penelitian ini, peneliti menggunakan dua model analisis faktor konfirmasi, yaitu analisis faktor konfirmasi tingkat satu dan analisis analisis faktor konfirmasi tingkat kedua. 


\subsubsection{Hasil Analisis Faktor Konfirmatori 1}

Menurut Kuncoro (2009), untuk mendapatkan data yang baik, perlu dilakukan pengujian skala pengukuran dengan uji validitas dan reliabilitas.

Dari hasil pengujian validitas, dapat diketahui bahwa semua indikator memiliki nilai loading factor di atas 0,5. Hal ini menunjukan untuk semua indikator dari iklim keselamatan(IK), pengetahuan $(\mathrm{P})$, motivasi $(\mathrm{M})$, kepatuhan keselamatan $(\mathrm{KK})$ dan partisipasi keselamatan $(\mathrm{PK})$, memiliki data yang valid dikarenakan memenuhi syaraat yang ditentukan. Sedangkan untuk pengujian reliabilitas, dapat diketahui bahwa semua variabel memiliki nilai Construct Reliability diatas 0,7 . Hal ini menunjukan untuk variabel iklim keselamatan(IK), pengetahuan $(\mathrm{P})$, motivasi $(\mathrm{M})$, kepatuhan keselamatan $(\mathrm{KK})$ dan partisipasi keselamatan $(\mathrm{PK})$, memiliki data yang reliabel dikarenakan memenuhi syaraat yang ditentukan

Dari hasil pengujian Goodness of Fit keseluruhan variabel, dapat diketahui bahwa hasil RMSEA, GFI, CFI dan TLI cukup baik, karena memiliki nilai diantara 0-1. Oleh sebab itu, maka dapat disimpulkan bahwa untuk semua indikator yang digunakan dapat mengukur setiap variabel yang ada dalam penelitian ini.

\subsubsection{Hasil Analisis Faktor Konfirmatori 2}

Analisis faktor konfirmasi tingkat kedua dalam penelitian ini digunakan untuk menguji faktorial dari semua indikator yang menjadi penyusun variabel perilaku keselamatan yaitu kepatuhan keselamatan (KK) dan partisipasi keselamatan (PK) : iklim keselamatan (IK), Pengetahuan $(\mathrm{P})$, motivasi (M). Selanjutnya, model pengaruh iklim keselamatan terhadap perilaku keselamatan dengan determinan pengetahuan dan motivsi pada proyek konstruksi dapat dijelaskan pada Gambar 1.

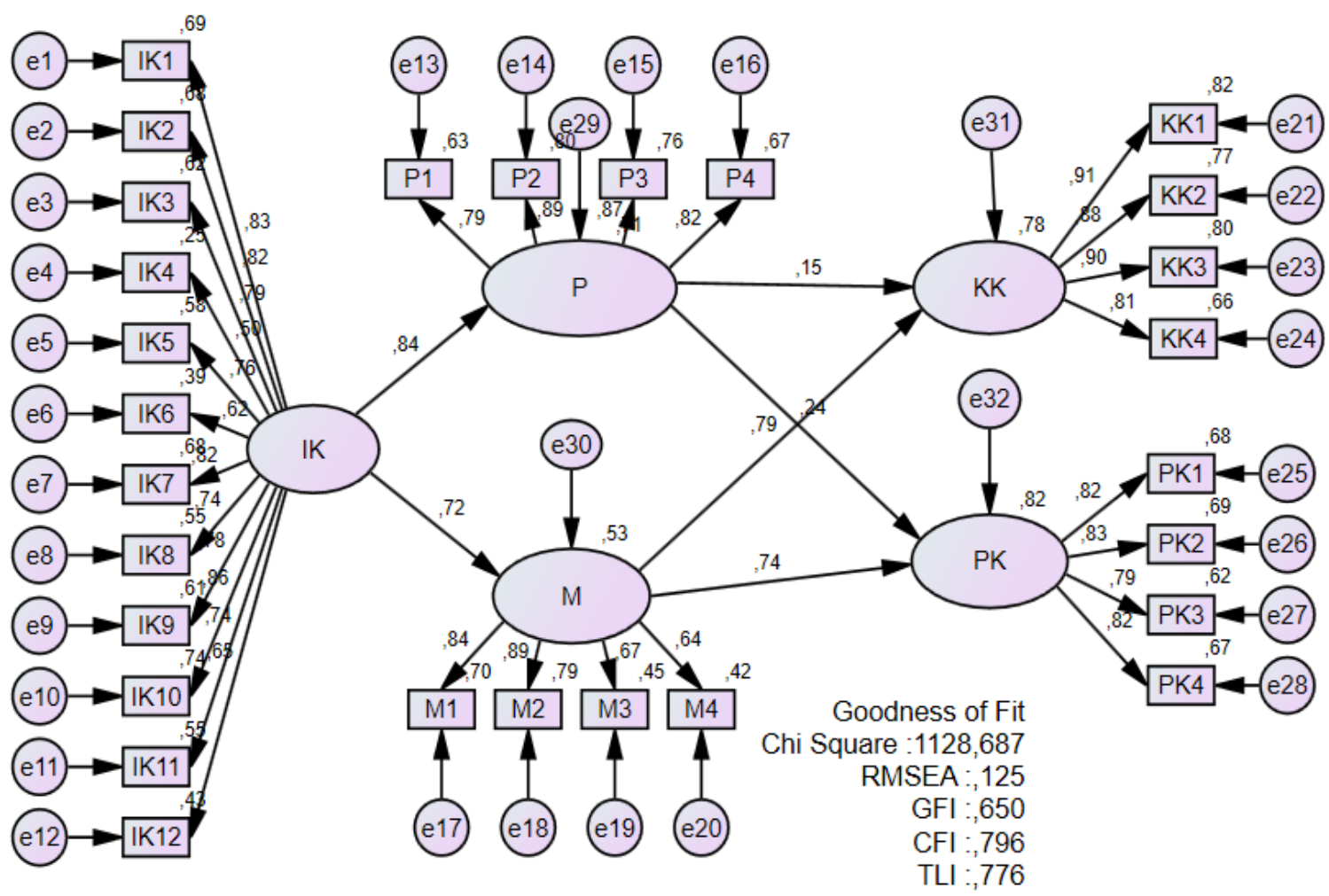

Gambar 1. Model Pengaruh Iklim Keselamatan terhadap Perilaku Keselamatan dengan Determinan Pengetahuan dan Motivasi pada Proyek Konstruksi 
Tabel 5. menunjukkan hasil goodness of fit dari model pengaruh iklim keselamatan terhadap perilaku keselamatan dengan determinan pengetahuan dan motivasi pada proyek konstruksi. Secara umum nilai goodness of fit yang dihasilkan dalam penelitian di anggap tidak fit. Ada beberapa kemungkinan yang mempengaruhi hasil model antara lain keterbatasan jumlah sampel yang digunakan dalam penelitian, ketidakpahaman responden terhadap pertanyaan penelitian, serta kemungkinan pengkajian teoritis kurang mendalam sehngga indikator yang digunakan dalam penelitian terbatas.

Tabel 5. Hasil Goodness of Fit

\begin{tabular}{|l|c|c|c|}
\hline Goodness of Fit & Cut-off Value & Hasil Model & Keterangan \\
\hline Chi Square & Diharapkan kecil & 1128,687 & Cukup Baik \\
\hline RMSEA & $0-1 / \leq 0,080$ & 0,125 & Cukup Baik \\
\hline GFI & $0-1 / \geq 0,900$ & 0,650 & Cukup Baik \\
\hline CFI & $0-1 / \geq 0,94$ & 0,796 & Cukup Baik \\
\hline TLI & $0-1 / \geq 0,95$ & 0,776 & Cukup Baik \\
\hline
\end{tabular}

Tabel 6. Hasil pengujian hipotesa dapat diketahui bahwa iklim keselamatan mempunyai pengaruh positif signifikan terhadap terhadap pengetahuan dan motivasi. Maka hipotesa "diduga iklim keselamatan mempengaruhi pengetahuan dan motivasi' didukung dan terbukti kebenarannya. Sedangkan pengetahuan mempunyai pengaruh positif tapi tidak signifikan terhadap kepatuhan keselamatan dan pengetahuan mempunyai pengaruh positif signifikan terhadap partisipasi keselamatan, maka hipotesa "diduga pengetahuan mempengaruhi kepatuhan keselamatan" tidak terbukti kebenarannya dan hipotesa "diduga pengetahuan mempengaruhi partisipasi keselamatan" didukung dan terbukti kebenarannya. Dan motivasi mempunyai pengaruh positif signifikan terhadap kepatuhan keselamatan dan partisipasi keselamatan. maka hipotesa "diduga motivasi mempengaruhi kepatuhan keselamatan dan partisipasi keselamatan' didukung dan terbukti kebenarannya.

Tabel 6. Hasil Pengujian Hipotesa

\begin{tabular}{|l|c|l|r|c|}
\hline \multicolumn{3}{|c|}{ Direct Effect } & Estimate & P \\
\hline PENGETAHUAN & $<--$ & IKLIM & 0.844 & 0,000 \\
\hline MOTIVASI & $<--$ & IKLIM & 0,725 & 0,000 \\
\hline PARTISIPASI & $<---$ & PENGETAHUAN & 0,244 & 0,003 \\
\hline KEPATUHAN & $<---$ & MOTIVASI & 0,787 & 0,000 \\
\hline KEPATUHAN & $<---$ & PENGETAHUAN & 0,147 & 0,059 \\
\hline PARTISIPASI & $<---$ & MOTIVASI & 0,737 & 0,000 \\
\hline
\end{tabular}

\section{KESIMPULAN DAN SARAN}

\subsection{Kesimpulan}

Dari ke 28 indikator yang digunakan dalam penelitian, untuk variabel iklim keselamatan (IK) yang memiliki loading factor terbesar adalah indikator komitemen manajemen (IK10), maka perlu dilakukan peningkatkan terhadap indikator komitmen manajemen dengan merencanakan program keselamatan kerja, beserta kebijakan yang diperlukan. untuk variabel pengetahuan $(P)$ yang memiliki loading factor terbesar adalah indikator mampu 
mempertahankan atau meningkatkan kesehatan dan keselamatan kerja (P2) maka perlu dilakukan peningkatkan terhadap indikator mampu mempertahankan atau meningkatkan kesehatan dan keselamatan kerja, dengan mengikuti pelatihan-pelatihan keselamatan dan mencari informasi-informasi terbaru tentang keselamatan, guna menambah wawasan tentang keselamatan. Untuk variabel motivasi $(\mathrm{M})$ yang memiliki loading factor terbesar adalah indikator suka melakukan pekerjaan dengan cara yang aman dan hati-hati (M2) maka itu perlu dilakukan peningkatkan terhadap indikator suka melakukan pekerjaan dengan cara yang aman, dengan pemberian insetif dan penghargaan, sehingga pekerja dapat termotivasi untuk melakukan pekerjaan dengan cara yang aman. Untuk variabel kepatuhan keselamatan (KK) yang memiliki loading factor terbesar adalah indikator menaati prosedur kerja (KK1) dan untuk variabel partisipasi keselamatan (PK) yang memiliki loading factor terbesar adalah indikator menghadiri rapat keselamatan, maka Untuk itu perlu dilakukan peningkatkan terhadap indikator menaati prosedur kerja dan indikator menghadiri rapat keselamatan, dengan penerapan program behavior based (BBS). Salah satu penerapannya dengan memberikan penghargaan untuk pekerja yang dapat melalukan pekerjaan dengan prosedur yang benar.

Dari hasil analisis SEM, iklim keselamatan mempunyai pengaruh iklim keselamatan mempunyai pengaruh positif signifikan terhadap terhadap pengetahuan dan motivasi. Sedangkan pengetahuan mempunyai pengaruh positif tapi tidak signifikan terhadap kepatuhan keselamatan dan pengetahuan mempunyai pengaruh positif signifikan terhadap partisipasi keselamatan. Dan motivasi mempunyai pengaruh positif signifikan terhadap kepatuhan keselamatan dan partisipasi keselamatan.

\subsection{Saran}

Untuk meningkatkan perilaku keselamatan pada suatu proyek konstruksi maka sebaiknya pihak kontraktor untuk menetapkan kebijakan-kebijakan yang berhubungan dengan motivasi dan pengetahuan yang berkaitan dengan keselamata kerja serta merencanakan dan menciptakan iklim keselamatan yang baik pada proyek konstruksi dan faktor iklim keselamatan juga harus diperhatikan oleh pihak kontraktor, karena faktor-faktor tersebut dapat memberikan kontribusi positif pada pengetahuan dan motivsi keselamatan. Sedangkan untuk penelitian selanjutnya kemungkinan bisa dilakukan moderating untuk pengetahuan dan motivasi, penambahan jumlah indikator yang digunakan untuk setiap variabel yang ada, sehingga indikator yang ada juga dapat mewakili variabel tersebut secara keseluruhan dan penambahan jumlah responden, sehingga hasil SEM dapat menghasilkan nilai goodness of fit yang lebih baik dan persentasi jumlah responden juga harus sama banyak untuk setiap jenjang dari data responden

\section{DAFTAR REFERENSI}

Borman, W. C. \& Motowidlo, S. J. (1993). "Expanding the Criterion Domain to Include Elements of Contextual Performance". In N. Schmitt \&. W. C. Borman (Eds), Personnel Selection in Organizations. Jossey-Bass. San Fancisco.

Cooper, M. D. \& Phillips, R. A. (2004). "Safety Climate Factors and Its Relationship with Accidents and Personal Attributes in The Chemical Industry." Journal of Safety Research, 35, 497-512.

Glendon, A. I. \& Litherland, D. K. (2001). "Safety Climate Factors, Group Differences and Safety Behavior in Road Construction." Safety Science, 39, 157-188.

Guo, B. H. W., Yiu, T. W., Gonzalez, V. A. (2016). "Predicting Safety Behavior in the Construction Industry: Development and Test of an Integrative Model." Safety Science, 84, 1-11. 
Liu, X., Huang, G., Huang, H., Wang, S., Xiao, Y., Chen, W. (2015). "Safety Climate, Safety Behavior, and Worker Injuries in The Chinese Manufacturing Industry." Safety Science, 78, 173-178

Munandar, M. (2001). Budgeting, Perencanaan Kerja Pengkoodinasian Kerja Pengawasan Kerja. BPFE Universitas Gajah Mada. Yogyakarta.

Neal, A. \& Griffin, M. A. (2000). "Perceptions of Safety at Work: A Framework for Linking Safety Climate to Safety Performance, Knowledge, and Motivation." Education Publishing Foundation, 5 (3), 347-358.

Neal, A., Griffin, M. A., Hart, P. M. (2000). "The Impact of Organizational Climate on Safety Climate and Individual Behavior." Safety Science, 34, 99-109.

Seo, D. C., Torabi, M. R., Blair, E. H., Ellis, N. T. (2004). "A Cross-Validation of Safety Climate Scale Using Confirmatory Factor Analytic Approach." Journal of Safety Research, 35, 427-445

Teo, E. A. \& Feng, Y. (2009). "The Role of Safety Climate in Predicting Safety Culture on Construction Sites." Architectural Science Review, 52 (1), 5-16.

Vinodkumar, M. N. \& Bhasi, M. (2009). "Safety Climate Factors and Its Relationship with Accidents and Personal Attributes in The Chemical Industry." Safety Science, 47, 659_ 667. 